\title{
Conduction velocity of the rabbit facial nerve: a noninvasive functional evaluation
}

\section{Velocidade de condução no nervo facial do coelho: uma avaliação funcional não invasiva}

\author{
Belmiro Cavalcanti do Egito Vasconcelos* \\ Cosme Gay Escoda** \\ Ricardo José de Holanda Vasconcellos*** \\ Riedel Frota Sá Nogueira Neves ${ }^{* * * *}$
}

\begin{abstract}
The aim of this study was to evaluate standardized conduction velocity data for uninjured facial nerve and facial nerve repaired with autologous graft nerves and synthetic materials. An evaluation was made measuring the preoperative differences in the facial nerve conduction velocities on either side, and ascertaining the existence of a positive correlation between facial nerve conduction velocity and the number of axons regenerated postoperatively. In 17 rabbits, bilateral facial nerve motor action potentials were recorded pre- and postoperatively. The stimulation surface electrodes were placed on the auricular pavilion (facial nerve trunk) and the recording surface electrodes were placed on the quadratus labii inferior muscle. The facial nerves were isolated, transected and separated $10 \mathrm{~mm}$ apart. The gap between the two nerve ends was repaired with autologous nerve grafts and PTFE-e (polytetrafluoroethylene) or collagen tubes. The mean of maximal conduction velocity of the facial nerve was $41.10 \mathrm{~m} / \mathrm{s}$. After 15 days no nerve conduction was evoked in the evaluated group. For the period of 2 and 4 months the mean conduction velocity was approximately $50 \%$ of the normal value in the subgroups assessed. A significant correlation was observed between the conduction velocity and the number of regenerated axons. Noninvasive functional evaluation with surface electrodes can be useful for stimulating and recording muscle action potentials and for assessing the functional state of the facial nerve.
\end{abstract}

DESCRIPTORS: Nerve regeneration; Electrophysiology; Neural conduction.

RESUMO: O objetivo deste estudo foi avaliar os dados padronizados de velocidade de condução para o nervo facial não lesado e o nervo facial reparado com enxerto autógeno e com materiais sintéticos. Na avaliação foram medidas as diferenças pré-operatórias de velocidade de condução do nervo facial em cada lado e verificada a existência de uma correlação positiva entre a velocidade de condução do nervo facial e o número de axônios regenerados no pós-operatório. O potencial de ação motora bilateral do nervo facial de 17 coelhos foi registrado no pré e no pós-operatório. Os eletrodos superficiais de estimulação foram colocados no pavilhão auricular (tronco do nervo facial) e os eletrodos superficiais de gravação foram colocados no músculo quadratus labii inferior. Os nervos faciais foram isolados, transeccionados e separados a $10 \mathrm{~mm}$. O espaço entre os dois cotos nervosos terminais foi reparado com enxertos nervosos autólogos e PTFE-e (politetrafluoretileno) ou tubos de colágeno. A média da máxima velocidade de condução do nervo facial foi $41,10 \mathrm{~m} / \mathrm{s}$. Nenhuma condução nervosa foi observada no grupo avaliado após 15 dias. A velocidade de condução média nos subgrupos avaliados para o período de 2 e 4 meses foi de aproximadamente $50 \%$ do valor normal. A avaliação funcional não invasiva com eletrodos de superficie pode ser útil para a estimulação e registro do potencial de ação muscular e para medir o estado funcional do nervo facial.

DESCRITORES: Regeneração nervosa; Eletrofisiologia; Condução nervosa.

\section{INTRODUCTION}

Nerve conduction data are used routinely in the diagnosis of peripheral neuropathies and other conditions ${ }^{1,14,26}$. Surface electrodes have been used for stimulating and recording the muscle action potentials. Normally three different types of electrodes are used in electromyography: surface, nee- dle and implanted electrodes ${ }^{15,16,30}$. The recording of peripheral nerves conduction velocity by directly stimulating and recording the surgically exposed nerves is one of the most precise approaches to nerve regeneration and muscle reinnervation. However, such single brief recordings makes it difficult to evaluate the nerve regeneration process

\footnotetext{
${ }^{*}$ Head Professor; ***Assistant Professor; ${ }^{* * *}$ Student of the PhD Program - Oral and Maxillofacial Surgery, School of Dentistry, University of Pernambuco.

${ }^{* *}$ Head Professor of Oral and Maxillofacial Surgery, School of Dentistry, University of Barcelona.
} 
Vasconcelos BC do E, Escoda CG, Vasconcellos RJ de H, Neves RFSN. Conduction velocity of the rabbit facial nerve: a noninvasive functional evaluation. Pesqui Odontol Bras 2003;17(2):126-31.

over time ${ }^{20,30}$. On the other hand, needle electrodes and electrodes implanted around peripheral nerves for sustained periods of time may generate artifacts that interfere with the interpretation of the effects of nerve injury ${ }^{15,16,19,20,30}$. Furthermore, infection also may occur as a result of invasive puncture with needles or the surgical implantation of devices, in particular when percutaneous contacts are used ${ }^{15,30}$.

Contrasting with needle and implanted electrodes, surface electrodes require no surgery, and evaluations can be repeated over sustained periods of time thereby affording an acceptable measurement approach ${ }^{3,9,19,20,25,30}$. Nerve conduction velocity is calculated by dividing the interelectrode distance by the latency of the first positive deflection in the waveform ${ }^{4,13}$.

The present experimental model studied normal conduction velocity in the rabbit facial nerve before surgery, and across facial nerve repaired with autologous nerve grafts and synthetic materials, with the aim of establishing the effectiveness of noninvasive functional testing.

\section{MATERIALS AND METHODS}

The stimulation and recording of antidromic evoked motor action potentials were carried out in 17 male New Zealand white rabbits ( 2.5 to $3.0 \mathrm{~kg}$ ). The animals were anesthetized with an intramuscular injection of a mixture of ketamine $50 \mathrm{mg} / \mathrm{kg}$ $\left(\right.$ Ketolar $^{\circledR}$, Parke-Davis, El Prat Llobregat, Barcelona, Spain) and acepromazine maleate $5 \mathrm{mg} / \mathrm{kg}$ (Calmo neosan ${ }^{\circledR}$, SmithKline-Beechan, Madrid, Spain), repeated as necessary. In addition, local anaesthesia with 3\% mepivacaine (Isogaine ${ }^{\circledR}$, Clarben, Madrid, Spain) was applied via subcutaneous injection in the surgical area. A mandibular incision towards the preauricular area identified the facial nerve. All animals were subjected to noninvasive functional study before and after surgery.

\section{Nerve lesions}

The buccal division of the facial nerve on each side and distally to the parotid gland was identified and isolated. A $10 \mathrm{~mm}$ segment was removed from the buccal division of the facial nerve in all cases ( $\mathrm{n}=34$, nerves) (Figure 1). The defects, in turn, were repaired with autologous nerve grafts, collagen and polytetrafluoroethylene (PTFE-e) conduits (Figures 2, 3 and 4). The autologous nerve grafts were obtained from the left facial nerve, of the same animal.

The animals recovered from the surgery on heated pads and were housed in individual cages, with free access to food and water. All animals survived the surgery without problems. At the completion of the study, all rabbits were sacrificed with overdose of sodium pentobarbital via an intracardiac injection.

After sacrifice, the anastomotic sites, graft or conduits plus a segment of approximately $5 \mathrm{~mm}$ from the proximal and distal nerve stumps were removed and marked. All specimens were fixed in glutaraldehyde and stained with toluidine blue. Cross-sectional biopsy specimens were examined under light microscopy $(100 \mathrm{X})$ to assess intraneural morphology. The axon counts were obtained in the sections from the midpoint of the primary anastomosis.

\section{Electrophysiological studies}

Electrophysiological analysis was performed following anesthesia. The stimulation surface electrodes were placed on the auricular pavilion (facial nerve trunk) and the recording surface electrodes were placed on the quadratus labii inferior muscle. Evoked muscle action potential was recorded by electromyography (Medelec MS25 Mistro, Surrey, England). Normal conduction velocity for the right and left facial nerve was recorded pre- and postoperatively. Conduction velocities were evoked across the reconstructed defect in the postoperative period, after peripheral nerve repair the rabbits were evaluated at 15 days and at 1,2 and 4 months, and correlated to the number of axons regenerated.

\section{Statistical Analysis}

Data analysis of the results was performed using the SPSS 7.5 (Statistical Package for Social Science - Microsoft, Illinois, Chicago, USA). Conduction velocity comparisons between the two sides (left and right) were made with the Student $t$-test for paired data. Correlations between conduction velocity and regenerated axon count were in turn evaluated by Pearson correlation analysis.

\section{RESULTS Normal conduction velocity}

Bilateral facial nerve conduction tracings were obtained for each of the 17 rabbits studied. There were no untoward events or complications. The 
Vasconcelos BC do E, Escoda CG, Vasconcellos RJ de H, Neves RFSN. Conduction velocity of the rabbit facial nerve: a noninvasive functional evaluation. Pesqui Odontol Bras 2003;17(2):126-31.

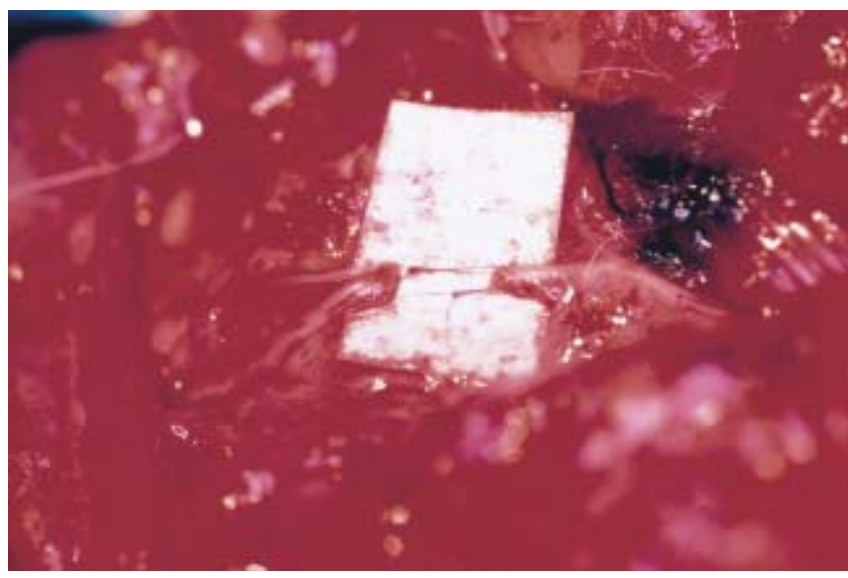

FIGURE 1 - Segment removed from the buccal division of the facial nerve.

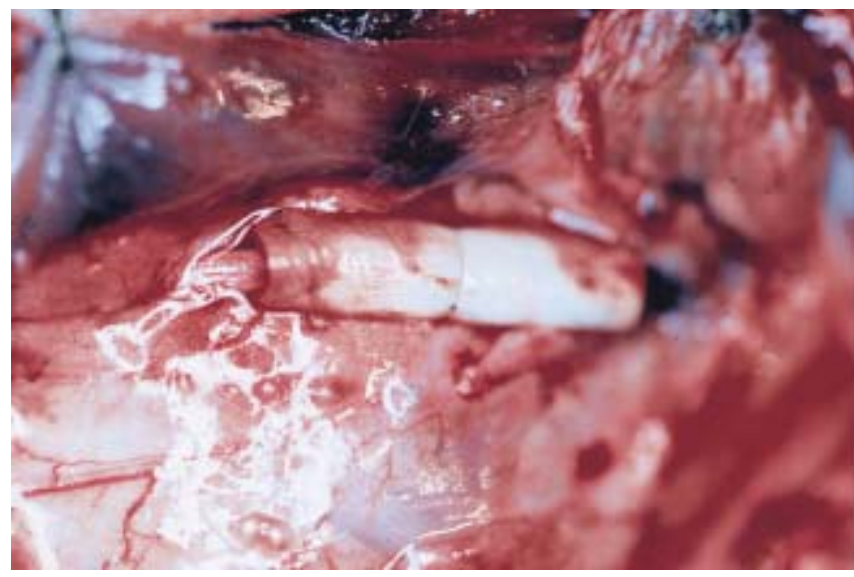

FIGURE 3 - Repair with collagen.

mean normal right conduction velocity evoked preoperatively was $41.27 \pm 3.27 \mathrm{~m} / \mathrm{s}$, versus $40.92 \pm 2.71 \mathrm{~m} / \mathrm{s}$ on the left side. Nerve conduction velocity at the peak of the signal was $47.05 \mathrm{~m} / \mathrm{s}$. There were no statistically significant differences between sides at the $95 \%$ confidence level (Student $t$-test, $\mathrm{p}=0.67)$. The mean global normal conduction velocity evoked before surgery was $41.10 \pm 2.97 \mathrm{~m} / \mathrm{s}$.

\section{Postoperative nerve conduction velocity}

No nerve conduction was evoked in the animals evaluated after 15 days, while the mean conduction velocity recorded after 2 and 4 months was approximately $50 \%$ of the normal value. The conduction velocity evoked at 4 months was $21.21 \pm 8.46 \mathrm{~m} / \mathrm{s}$ (repair with nerve graft) and $18.26 \pm 5.69 \mathrm{~m} / \mathrm{s}$ (repair with polytetrafluoroethylene tube).

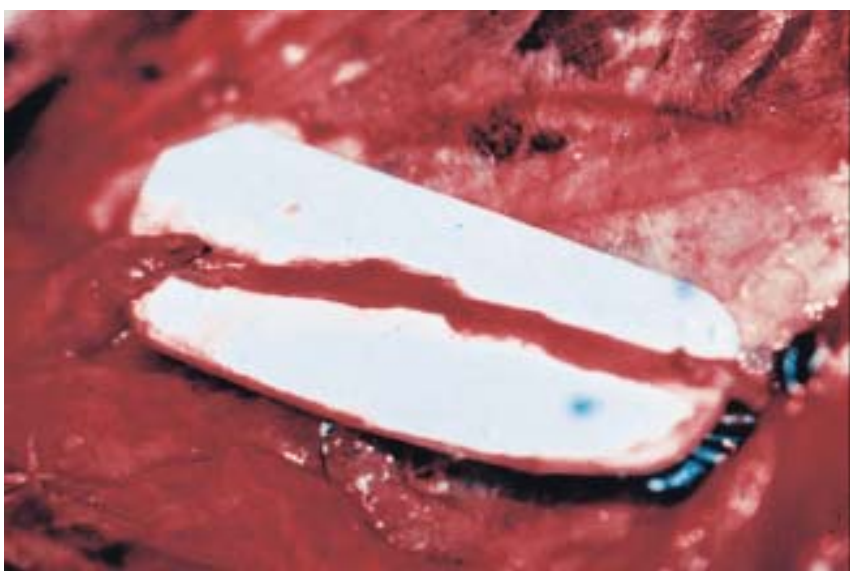

FIGURE 2 - Repair with autologous nerve grafts.

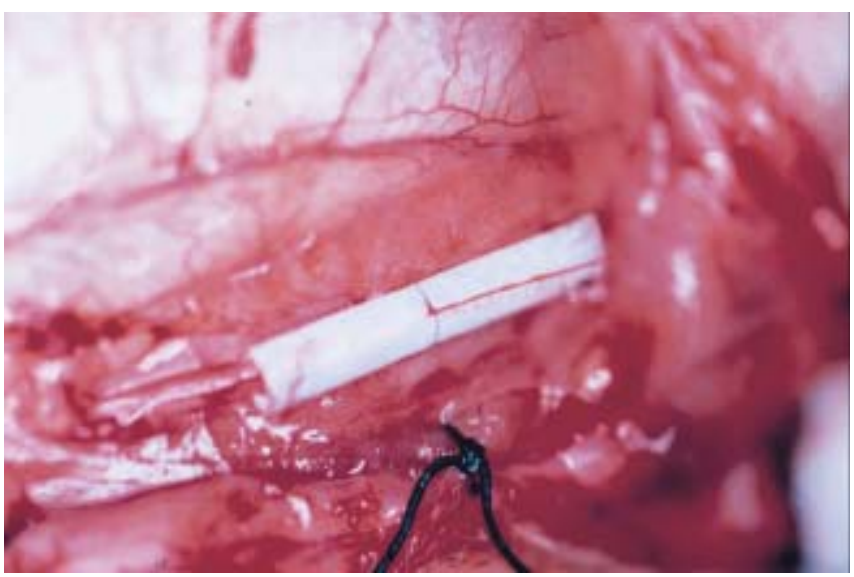

FIGURE 4 - Repair with polytetrafluoroethylene (PTFEe) conduits.

The conduction velocity at 2 months for the polytetrafluoroethylene tube and colagen groups were $22.95 \pm 6.52 \mathrm{~m} / \mathrm{s}$ and $24.11 \pm 6.12 \mathrm{~m} / \mathrm{s}$ and the results at 4 months were $21.68 \pm 3.7 \mathrm{~m} / \mathrm{s}$ (polytetrafluoroethylene tube) and $23.29 \pm$ $2.47 \mathrm{~m} / \mathrm{s}$ (colagen).

\section{Normal axonal nerve}

The total number of myelinated axons ranged from 156.37 to 176.21 . The mean myelinated nerve count ( \pm standard deviation) was $166.29 \pm 9.45$ myelinated axons (oculoreticular area) (Figure 5).

\section{Postoperative axonal regeneration}

15 days after PTFE-e, autologous nerve grafts and collagen repair, an absence of axonal regeneration was observed (Figure 6). However, within 4 months, a good axonal regeneration was observed 
Vasconcelos BC do E, Escoda CG, Vasconcellos RJ de H, Neves RFSN. Conduction velocity of the rabbit facial nerve: a noninvasive functional evaluation. Pesqui Odontol Bras 2003;17(2):126-31.

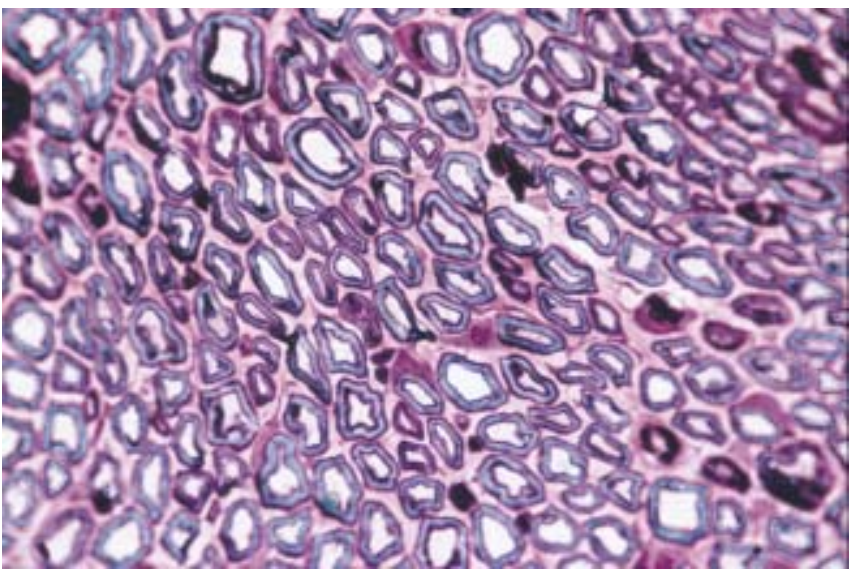

FIGURE 5 - Myelinated axons of the normal buccal divisions of the facial nerve (toluidine blue, $100 \mathrm{X}$ ).

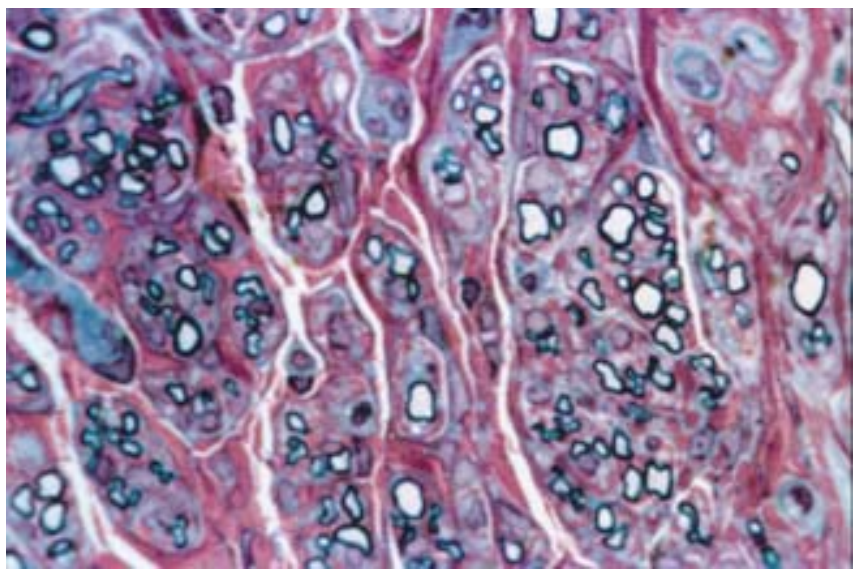

FIGURE 7 - Axonal regeneration at 4 months after PTFE-e conduit repair.

for all groups (Figure 7). In the postoperative period, a significant correlation between conduction velocity and axonal regeneration was observed for all groups and techniques $(n=34 ; 0,002$ - Pearson test).

\section{DISCUSSION}

One of the challenges of peripheral nerve regeneration is the early and quantitative assessment of the regeneration process in terms of the number of active axons found in the bundle. Reinnervation dynamics can be studied using different techniques ${ }^{6,17,24,28}$. In the present study the efficacy of a noninvasive method was evaluated in an application in a rabbit model.

The use of single-fiber electromyography for evaluating the microphysiology of an individual motor unit has been described in the literature.

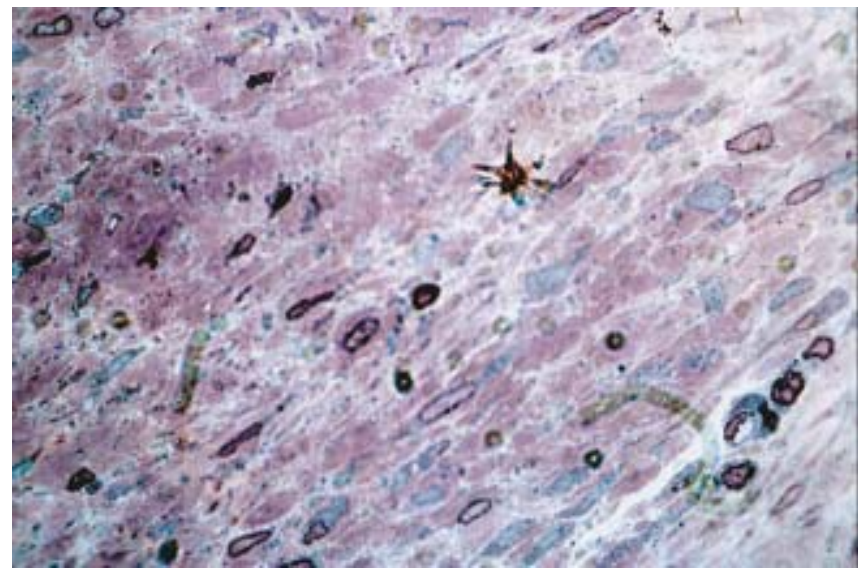

FIGURE 6 - Absence of axonal regeneration at 15 days after PTFE-e conduit repair.

This technique can be used to study the denervation and reinnervation occurring as a result of peripheral nerve injury ${ }^{29}$.

A comparative study between magnetic nerve stimulation with conventional electric nerve stimulation in normal subjects and in patients with disorders of the peripheral nervous system has been reported. In general, both nerve stimulation modalities yielded similar results in patients with disorders and healthy subjects ${ }^{2}$.

The literature reports an evaluation of the inferior alveolar nerve function using a repeated nerve conduction test during mandibular sagittal split osteotomy. The intraoperative sensory nerve conduction velocity recorded and the mental nerve blink reflex tests conducted two weeks after the operation were correlated, whereas comparison of clinical neurosensory testing with the intraoperative events and sensory conduction velocities was less consistent ${ }^{11}$.

Another research studied conduction velocity of the deep temporal nerve and the mylohyoid nerve motor branches of the trigeminal nerve. These nerves were stimulated intraorally with a pediatric surface stimulator. Compound muscle action potentials were recorded over the temporalis and mylohyoid muscles using surface electrodes. The mean latency of the deep temporal nerve was $2.1 \mathrm{~m} / \mathrm{s} \pm 0.3 \mathrm{~m} / \mathrm{s}$, versus $1.9 \mathrm{~m} / \mathrm{s} \pm 0.2 \mathrm{~m} / \mathrm{s}$ for the mylohyoid nerve. The maximal side-to-side latency difference was $0.4 \mathrm{~m} / \mathrm{s}$. These authors concluded that such techniques should prove useful in patients with trigeminal nerve disorders ${ }^{5}$.

A new technique for recording sensory conduction velocity of the inferior alveolar nerve was re- 
Vasconcelos BC do E, Escoda CG, Vasconcellos RJ de H, Neves RFSN. Conduction velocity of the rabbit facial nerve: a noninvasive functional evaluation. Pesqui Odontol Bras 2003;17(2):126-31.

ported by Jaaskelainen ${ }^{12}$. The sensory responses of this nerve were obtained in all 42 nerves examined with silver wire or monopolar needle electrodes inserted beneath the zygomatic arch, anteriorly to the temporomandibular joint and to a depth of 4 to $4.5 \mathrm{~cm}$, near the oval foramen. A small bipolar surface electrode was used for stimulation at the mental foramen. The mean sensory conduction velocity of the inferior alveolar nerve was $62.8 \mathrm{~m} / \mathrm{s} \pm$ $6.7 \mathrm{~m} / \mathrm{s}$ on the right side, and $63.0 \mathrm{~m} / \mathrm{s} \pm 5.4 \mathrm{~m} / \mathrm{s}$ on the left side.

The influence of temperature ${ }^{7,8,22}$, age ${ }^{18,23}$, and height ${ }^{21,23}$ upon conduction velocity has been described by a number of authors. Frassen et al. ${ }^{11}$ reported differences in evoked potential at different temperature in humans. Our own observations show mean conduction velocity of the facial nerve $(41.10 \mathrm{~m} / \mathrm{s})$ at $25^{\circ} \mathrm{C}$ to be similar to the results reported by Frassen et al. $(45.0 \mathrm{~m} / \mathrm{s})^{8}$. In this case, environmental temperature and age of the animals were controlled. In addition, the mean conduction velocity of the facial nerve was consistent with values previously reported in the literature (range

\section{REFERENCES}

1. Barker GR, Bennett AJ, Wastell DG. Applications of trigeminal somatosensory evoked potentials (TSEPs) in oral and maxillofacial surgery. Br J Oral Maxillofac Surg $1987 ; 25: 308-13$.

2. Binkofski F, Classen J, Benecke R. Stimulation of peripheral nerves using a novel magnetic coil. Muscle Nerve 1999;22:751-7.

3. Colin WB, Donoff RB. Electrodiagnostic evaluation of the uninjured rabbit inferior alveolar nerve. J Oral Maxillofac Surg 1990;48:170-3.

4. Colin WB. Conduction velocity of the human inferior alveolar nerve: a preliminary report. J Oral Maxillofac Surg 1993;51:1018-23.

5. Dillingham TR, Spellman NT, Chang AS. Trigeminal motor nerve conduction: deep temporal and mylohyoid nerves. Muscle Nerve 1996;19:277-84.

6. Dorfman LJ. Quantitative clinical electrophysiology in the evaluation of nerve injury and regeneration. Muscle Nerve 1990;13:822-8.

7. Frassen H, Wieneke GH. Nerve conduction and temperature: necessary warming time. Muscle Nerve 1994; 17:336-44.

8. Frasesen H, Wieneke GH, Wokke JHJ. The influence of temperature on conduction block. Muscle Nerve 1999;22:166-73.

9. Godfrey RM, Mitchell KW. Somatosensory evoked potentials to electrical stimulation of the mental nerve. Br J Oral Maxillofac Surg 1987;25:300-7.

10. Huang TC, Blanks RHI, Crumley RL. Laser-assisted nerve repair. Arch Otolaryngol Head Neck Surg 1992; 118:277-80.
35.0-64.6 m/s) ${ }^{8,10,27}$. There were no significant serial differences between the results of conduction velocity between the left and right facial nerves. Ours results agree with those reported by Colin et $a .^{3}$.

In this study a significant correlation between the conduction velocity and the number of regenerated axons involving different techniques was observed $(\mathrm{p}<0.01 ; \mathrm{r}=0.002)$. This could explain why the study variables exhibited an increasing tendency during nerve regeneration.

\section{CONCLUSION}

In all groups and techniques, a significant correlation between conduction velocity and axonal regeneration was observed.

Noninvasive functional evaluation with surface electrodes can be useful for stimulating and recording muscle action potentials and for assessing the functional state of the facial nerve following injury or surgery.

11. Jaaskelainen SK, Peltola JK, Forssel K, Vahatalo K. Evaluating function of the inferior alveolar nerve with repeated nerve conduction tests during mandibular sagittal split osteotomy. J Oral Maxillofac Surg 1995;53:269-79.

12. Jaaskelainen SK. A new technique for recording sensory conduction velocity of the inferior alveolar nerve. Muscle Nerve 1999;22:445-9.

13. Jones DL, Thrash WJ. Electrophysiological assessment of human inferior alveolar nerve function. J Oral Maxillofac Surg 1992;50:581-5.

14. Kraft GH. Fibrillation potential amplitude and muscle atrophy following peripheral nerve injury. Muscle Nerve 1990;13:814-21.

15. Krarup C, Loeb GE. Conduction studies in peripheral cat nerve using implanted electrodes: I. Methods and findings in controls. Muscle Nerve 1988;11:922-32.

16. Krarup C, Loeb GE, Pezeshkpour GH. Conduction studies in peripheral cat nerve using implanted electrodes: II. The effects of prolonged constriction on regeneration of crushed nerve fibers. Muscle Nerve 1988;11:933-44.

17. Kuypers PDL, Gielen FLH, Wai RTJ, Hovius SER, Godschalk M, Egeraat JMV. A comparison of electric and magnetic compound action signals as quantitative assays of peripheral nerve regeneration. Muscle Nerve 1993; 16:634-41.

18. Lang HA, Puusa A, Hynninen P, Kuusela V, Jantti V, Sillanpaa M. Evolution of nerve conduction velocity in later childhood and adolescence. Muscle Nerve 1985;8:38-43.

19. Leandri M, Favale E. Diagnostic relevance of trigeminal evoked potentials following infraorbital nerve stimulation. J Neurosurg 1991;75:244-50. 
Vasconcelos BC do E, Escoda CG, Vasconcellos RJ de H, Neves RFSN. Conduction velocity of the rabbit facial nerve: a noninvasive functional evaluation. Pesqui Odontol Bras 2003;17(2):126-31.

20. Nelson KR, Vasconez HC. Nerve transection without neurotonic discharges during intraoperative electromyographic monitoring. Muscle Nerve 1995;18:236-8.

21. Rivner MH, Swift TR, Crout BO, Rhodes KP. Toward more rational nerve conduction interpretations: the effect of height. Muscle nerve 1990;13:232-9.

22. Rutkove SB, Kothari MJ, Shefner JM. Nerve, muscle, and neuromuscular junction electrophysiology at high temperature. Muscle Nerve 1997;20:431-6.

23. Soldres G, Andersson T, Borin Y, Brandt L, Persson A. Electroneurography index: a standardized method to assess peripheral nerve function in patients with polyneuropathy. Muscle Nerve 1993;16:941-6.

24. Stalbeg E. Use of single fiber EMG and macro EMG in study of reinnervation. Muscle Nerve 1990;13:804-13.

25. Terzis JK, Sun DD, Thanos PK. Historical and basic science review: past, present, and future of nerve repair. J Reconstr Microsurg 1997;13:215-25.
26. Vasconcelos BCE, Pereira Jr ED, Berini-Aytés L, Gay-Escoda C. Reparación microquirúrgica del nervio periférico. Técnicas y materiales. Rev Eur Odontoestomatol 1999;11:151-60.

27. Wells MR, Kraus K, Batter DK, Blunt DG, Weremowitz J, Lynch ES, et al. Gel matrix vehicles for growth factor application in nerve gap injuries repaired with tubes: a comparison of biomatrix, collagen, and methylcellulose. Exp Neurol 1997;146:395-402.

28. Wilgis EFS. Techniques for diagnosis of peripheral nerve loss. Clin Ortoph 1982;163:8-14.

29. Wiechers D. Single fiber EMG evaluation in denervation and reinnervation. Muscle Nerve 1990;13:829-32.

30. Zeng L, Worseg A, Albrecht G, Grisold W, Hopf R, Redl H, et al. A noninvasive functional evaluation following peripheral nerve repair with electromyography in a rat model. Plast Reconstr Surg 1994;94:146-51.

Recebido para publicação em 20/09/02

Enviado para reformulação em 20/01/03

Aceito para publicação em 16/05/03 